\title{
Dipeptidyl Peptidase 9
}

National Cancer Institute

\section{Source}

National Cancer Institute. Dipeptidyl Peptidase 9. NCI Thesaurus. Code C124982.

Dipeptidyl peptidase 9 ( $863 \mathrm{aa}, \sim 98 \mathrm{kDa}$ ) is encoded by the human DPP9 gene. This protein is involved in the removal of dipeptides from the amino-termini of substrates. 